\title{
Asymptomatic carriage of COVID-19 in pregnant women: a retrospective cohort study
}

\author{
Ruiling Xu ${ }^{1}$, Tara Pauley ${ }^{1}$, Hannah Missfelder-Lobos ${ }^{1}$, Richard Haddon ${ }^{2}$, and Hsu Chong ${ }^{1}$ \\ ${ }^{1}$ Rosie Maternity Hospital \\ ${ }^{2}$ Addenbrooke's Hospital
}

September 18, 2020

\begin{abstract}
OBJECTIVE Asymptomatic carriage of COVID-19 in pregnant women has been reported. We sought to ascertain the impact of high quality rapid PCR testing for COVID-19 in an unselected cohort of pregnant women attending our maternity unit. DESIGN Retrospective cohort analysis SETTING Cambridge, East of England POPULATION All pregnant women who were admitted to Rosie maternity unit over a 4-week period (May to June 2020) METHODS Pregnant women were screened for COVID-19 using nasopharyngeal and oropharyngeal swabs on admission. Samples were analysed using the SAMBA-II RT-PCR machine. Symptoms were defined as cough and/or fever that could not be attributed to an obstetric cause. RESULTS NP and OP swabs were obtained from $457 / 465$ women during the study period (98\%). The median turnaround time for results was 5.3 hours (IQR 2.6-8.9). 92\% of results were returned within 24 hours. In our cohort, only one woman tested positive, giving a screen positive rate of $0.2 \%(1 / 457)$. One woman who tested negative developed a fever postnatally following discharge but was lost to follow-up. There was no correlation between asymptomatic carriage and regional prevalence of COVID-19. CONCLUSIONS Testing using the SAMBA-II machine was acceptable to the vast majority of pregnant women requiring admission and had a low turnaround time. Asymptomatic carriage is low, but not correlated to community prevalence rates. Screening pregnant women on admission will remain an important component in order to minimise nosocomial infection and spread within healthcare workers as COVID-19 rates increase in the UK.
\end{abstract}

\section{Hosted file}

Samba_II_for_COVID-19_in_pregnant_women-_BJOG_FINAL.doc available at https://authorea.com/ users/360047/articles/481769-asymptomatic-carriage-of-covid-19-in-pregnant-women-aretrospective-cohort-study

\section{Hosted file}

Figure 1 Samba turnaround time graph FINAL.docx available at https://authorea.com/ users/360047/articles/481769-asymptomatic-carriage-of-covid-19-in-pregnant-women-aretrospective-cohort-study

\section{Hosted file}

Figure 2- Prevalence in pregnant women -FINAL.docx available at https://authorea.com/ users/360047/articles/481769-asymptomatic-carriage-of-covid-19-in-pregnant-women-aretrospective-cohort-study

\section{Hosted file}

Figure 3- Prevalence in asymptomatic carriers -FINAL.docx available at https://authorea. com/users/360047/articles/481769-asymptomatic-carriage-of-covid-19-in-pregnant-women-a- 
retrospective-cohort-study 